\title{
Baseline survey of the fish fauna of a highly eutrophic estuary and evidence for its colonisation by Goldfish (Carassius auratus)
}

\author{
James R. Tweedley (1) C Chris S. Hallett (1) - Stephen J. Beatty $($ )
}

Received: 2 June 2017/ Accepted: 18 August 2017/Published online: 14 September 2017

(C) The Author(s) 2017. This article is an open access publication

\begin{abstract}
This study represents the first quantitative survey of the fish fauna of the highly eutrophic Vasse and Wonnerup estuaries, part of the Ramsar-listed Vasse-Wonnerup Wetland System in south-western Australia. Sampling at five sites in each of these estuaries occurred in January 2012 (austral summer) to provide a species inventory and determine whether the number of species, total density and fish community composition differed between the two water bodies. A total of 18,148 fish were recorded, representing six species across four families. Three species that can complete their life cycle within estuaries, i.e. the atherinids Lepthatherina wallacei and Atherinosoma elongata and the gobiid Pseudogobius olorum, dominated the fish fauna, accounting for $>99 \%$ of all fish collected. No significant inter-estuary differences were observed in the mean number of species, mean total density or fish community composition. Although the fish community was depauperate in terms of the number of species, total density was high, reflecting the presence of permanent and seasonal barriers to the immigration of marine species into these estuaries and the highly productive nature of this system, respectively. Two introduced freshwater species, i.e. the Eastern Gambusia Gambusia holbrooki and the Goldfish, Carassius auratus, were recorded in the Vasse Estuary. As C. auratus was found in mesohaline conditions, individuals may be able to use the estuary as a 'saltbridge' to gain access to other tributaries and/or the Wonnerup Estuary, and thus expand their distribution. These findings are of concern given the potential deleterious biological and ecological effects of these alien species.
\end{abstract}

Keywords Introduced species $\cdot$ Ramsar $\cdot$ South-western Australia $\cdot$ Vasse-Wonnerup · Wetland

\section{Introduction}

It is widely recognised that, despite their many valuable ecosystem services (Costanza et al. 1997; Creighton et al. 2015; Sheaves et al. 2015), temperate estuaries are the most degraded of all aquatic ecosystems (Jackson et al. 2001). Microtidal systems, i.e. those with a tidal range $<2 \mathrm{~m}$, located in Mediterranean climate regions are particularly susceptible to degradation, due to their limited tidal water movement, highly seasonal rainfall and, in some cases, ephemeral connection to the ocean (Potter et al. 2010; Tweedley et al. 2016). These characteristics increase the residency time of water in the estuary and facilitate the trapping of fine sediments and contaminants (Patchineelam et al. 1999; Tweedley et al. 2016). Given the 'natural susceptibility' of microtidal estuaries, such as those in south-western Australia, to environmental degradation and the effects on

J. R. Tweedley $(\bowtie) \cdot$ C. S. Hallett · S. J. Beatty

School of Veterinary and Life Sciences, Centre for Fish and Fisheries Research, Murdoch University, 90 South Street, Murdoch, WA 6150, Australia

e-mail: j.tweedley@murdoch.edu.au 
these systems of increased urbanisation and eutrophication, it is unsurprising that the environmental health of some of these systems has been shown to have declined since the 1980s (Wildsmith et al. 2009; Tweedley et al. 2012, 2014).

One such system in south-western Australia that has experienced a suite of deleterious anthropogenic impacts is the Vasse-Wonnerup; a shallow, intermittently-open, nutrient-enriched system located near the town of Busselton, Western Australia (Brearley 2005; Commonwealth of Australia 2002). The system is comprised of the Vasse and Wonnerup estuaries and provides habitat, at any one time of the year, for over 37,500 water birds comprising $~ 90$ species, a function that is recognised by its designation as a Wetland of International Importance under the Ramsar Convention in 1990 (Lane et al. 2007). Although the importance of the Vasse-Wonnerup is well recognised, the system and surrounding land have been subjected to extensive anthropogenic modification. For example, much of the catchment has been cleared, primarily for cattle grazing; extensive drainage networks have been constructed; several rivers that used to flow into the system have been diverted to the sea and permanent surge barriers have been installed at the junction between each of the estuaries and Wonnerup Inlet to prevent seawater intrusion (Lane et al. 1997; Fig. 1). Moreover, the large amounts of fertilizer applied to agricultural land, combined with animal waste discharged from pastures into the estuaries, have resulted in the Vasse-Wonnerup becoming "the most grossly enriched major wetland system known in Western Australia" (McAlpine et al. 1989). Without management intervention nutrient loads are expected to increase further over the next 20 years due to increased urbanisation and more intensive agriculture (Department of Water 2010).

These anthropogenic pressures have had numerous impacts on the ecological health of the system. Fish kills, in particular, occur regularly in the Vasse-Wonnerup, with reports of such events dating back to 1905 and at least nine kills have occurred between 1984 and 2013 (Hart 2014). Anoxia, high water temperatures and

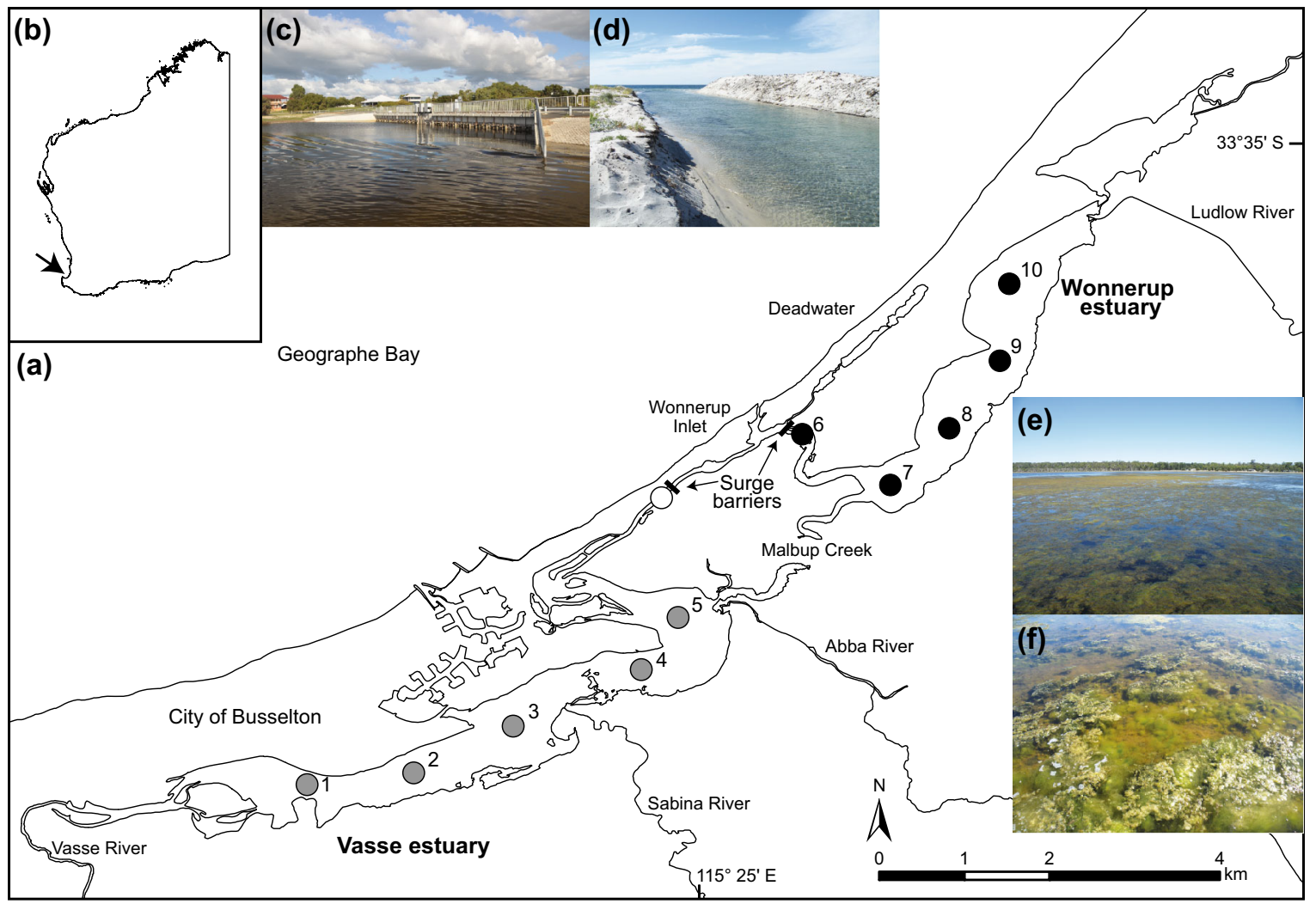

Fig. 1 a Map of the Vasse-Wonnerup Wetland System, showing the location of sites sampled in the Vasse (dark gray filled circle) and Wonnerup (filled circle) estuaries in January 2012. b denotes the location of Vasse-Wonnerup in Western Australia. $\mathbf{c}$ shows the Vasse surge barrier, which prevents the upstream flow of water, $\mathbf{d}$ the mouth of the estuary in Wonnerup Inlet and $\mathbf{e}$, f an algal bloom in the Vasse Estuary at the time of sampling. Open circle denotes the location where additional physico-chemical measurements were recorded 
hypersalinity, macroalgal blooms and/or toxic phytoplankton have all been considered the causes of these events (Lane et al. 1997; Hart 2014). However, despite the frequency of fish kills and the importance of this system to recreational and commercial fishers (Elscot 2000), no quantitative survey of the fish fauna of this estuary has been conducted. Such a study is fundamental to understanding the ecological functioning of this system, particularly as fish constitute a substantial component of the diet of at least 24 bird species found in the Vasse-Wonnerup (Wetland Research and Management 2007). Moreover, a population of the highly invasive Goldfish (Carassius auratus) is known to reside in the Lower Vasse River, which flows into the Vasse Estuary (Morgan and Beatty 2007; Beatty et al. 2017), thus posing a further potential threat to the ecology of this system.

Given the range of natural and anthropogenic pressures that threaten this internationally important system, the collection of the first quantitative data on the fish fauna would also allow the development of ecologically relevant tools for monitoring the future health of the system (Harrison and Whitfield 2004; Hallett et al. 2012; Tweedley et al. 2017). Such tools could help to provide a rigorous assessment of the effectiveness of management actions (Hallett et al. 2016), including recent efforts to reduce nutrient inputs (Department of Water 2010). The collection of these quantitative data would also help determine the level of threat posed by the population of invasive $C$. auratus in the Lower Vasse River.

The overall aim of this study was to conduct a baseline survey of the fish fauna of the Vasse and Wonnerup estuaries, the areas of the wetland system that are most important for the avian fauna (Lane et al. 1997). Specifically, the objectives were to (1) provide a quantitative description of the fish communities of the Vasse and Wonnerup estuaries, (2) determine whether the number of species, density and composition of the fish faunas differed between the two estuaries and (3) determine whether C. auratus were present in either of the estuaries.

\section{Materials and methods}

Sampling regime

Five sites in the shallow waters of each of the Vasse and Wonnerup estuaries were sampled in January 2012 (Fig. 1). At that time, the bar at the mouth of Wonnerup Inlet, which is intermittently-open to the ocean, was open having been artificially breached on December 14, 2011 and two narrow chutes (40 cm in width) in the Vasse and Wonnerup surge barriers were opened periodically to allow the movement of fish into and out of the estuaries (Fig. 1c). At each site, two samples of the fish fauna were collected using a seine net that was $21.5 \mathrm{~m}$ long and consisted of two $10 \mathrm{~m}$ long wings ( $6 \mathrm{~m}$ of $9 \mathrm{~mm}$ mesh and $4 \mathrm{~m}$ of $3 \mathrm{~mm}$ mesh) and a $1.5 \mathrm{~m}$ long bunt made of $3 \mathrm{~mm}$ mesh, fished to a depth of $1.5 \mathrm{~m}$ and swept an area of $\sim 116 \mathrm{~m}^{2}$. Upon capture, all fish were immediately euthanized in an ice slurry (Murdoch University Animal Ethics Permit R2450_11). The total number of individuals of each fish species in each sample was then recorded and the total length of each individual measured to the nearest $1 \mathrm{~mm}$, except when a large number of any one species was caught, in which case the lengths of a representative subsample of 100 fish were measured. Each species was assigned to an estuarine usage guild, based on the results of numerous studies of the biology of fish species in south-western Australian estuaries (e.g. Potter and Hyndes 1999). The ways in which fish use estuaries were considered to comprise four categories, i.e. marine, estuarine, diadromous and freshwater, with each containing multiple guilds (Potter et al. 2015a, b).

Salinity, water temperature and dissolved oxygen concentration and saturation were measured in the middle of the water column at each site at the time of fish collection and on the same day immediately upstream of the Vasse surge barriers using a Yellow Springs Instrument 556 water quality meter.

Statistical analyses

Environmental conditions and univariate measures of diversity

One-way analysis of variance (ANOVA) was employed to determine whether any of a suite of physicochemical variables, i.e. salinity, water temperature and dissolved oxygen concentration and saturation, and 
biotic variables, i.e. number of species and total density, differed significantly between the Vasse and Wonnerup estuaries. Prior to undertaking ANOVA, the data for each of the five dependent variables were subjected to the Anderson-Darling and $F$ test routines in Minitab 15 to ascertain the type of transformation, if any, required to meet the test assumptions of normality and equal variance among a priori groups. This showed that the data for each of the physico-chemical variables and the number of species required no transformation, but that total density required a square-root transformation. In all ANOVA tests the term Estuary ( 2 levels; Vasse and Wonnerup) was considered fixed and the null hypothesis of no significant differences between a priori groups was rejected if the significance level $(p)$ was $<0.05$.

\section{Multivariate analyses of fish faunal composition}

The abundances of the various fish species recorded were dispersion-weighted to down-weight the effects of those species whose numbers exhibited erratic differences among replicate samples due to schooling (Clarke et al. 2006), followed by a square-root transformation to down-weight the contributions of species with consistently high values (across replicates within a group) in relation to those with consistently low values (Veale et al. 2014). The two replicate samples from each site were averaged and the resultant pre-treated data used to construct a Bray-Curtis resemblance matrix which was, in turn, subjected to a one-way analysis of similarities (ANOSIM) test (Clarke and Green 1988) in PRIMER v7. This test was employed to determine whether the composition of the fish faunas of the two estuaries differed. The null hypothesis that there were no significant differences in fish faunal composition between a priori groups (i.e. the two estuaries) was rejected if the significance level $(p)$ was $<0.05$. The extent of any such significant difference was determined by the magnitude of the test statistic $(R)$, which typically ranges between $\sim 0$, i.e. no group differences, to 1 , i.e. the similarities between samples from different groups are always less than those between samples belonging to the same group. Non-metric Multidimensional Scaling (nMDS) ordination was then employed to display visually the ways in which the samples from each a priori group were distributed in low dimensional space according to their faunal compositions (Clarke 1993).

Similarity percentages (SIMPER; Clarke et al. 2014a) were used to identify those species that typified the fish fauna in each estuary and, if appropriate, those that were responsible for distinguishing between them. A shade plot was constructed from the dispersion-weighted, square-root transformed and averaged data and used to display the trends exhibited by the abundance of all fish species recorded. This shade plot is a simple visualisation of the frequency matrix, where a white space for a species demonstrates that that species was never collected, while the depth of shading from grey to black is linearly proportional to its abundance (Clarke et al. 2014b). Species ( $y$ axis) were clustered based on their Bray-Curtis similarities and placed in optimum serial order, constrained by the cluster dendrogram (Clarke et al. 2014a). Sites ( $x$ axis) were ordered based on their location in the two estuaries from most upstream to downstream, i.e. 1-5 in the Vasse Estuary and 10-6 in the Wonnerup Estuary (see Fig. 1).

\section{Results}

Environmental conditions

Salinities in January 2012 ranged from 17.1 to 19.4 in the Vasse Estuary and 14.2 to 17.3 in the Wonnerup Estuary. One-way ANOVA demonstrated that salinity differed significantly between estuaries $(p=0.005)$, with, on average, higher values being recorded in the Vasse $(18.3 \pm 0.44 \mathrm{SE})$ than the Wonnerup $(15.7 \pm 0.51 \mathrm{SE})$ Estuary (Table 1). Water temperature ranged from 24 to $31{ }^{\circ} \mathrm{C}$ across the ten sites, but did not differ significantly between the two estuaries $(p=0.678)$, being, on average, $\sim 28{ }^{\circ} \mathrm{C}$ (Table 1). Dissolved oxygen saturation was similar between estuaries $(p=0.520)$, exceeding $100 \%$ at nine of the ten sites, reaching $>200 \%$ in both estuaries and as high as $257 \%$, likely due to the large quantities of macroalgae present (Table 1; Fig. 1e, f). However, concentrations were, on average, $11.92( \pm 0.66 \mathrm{SE})$ and $13.80( \pm 2.18$ SE) $\mathrm{mgL}^{-1}$ in the Vasse and Wonnerup estuaries, respectively, and were found by one-way ANOVA not to differ significantly $(p=0.434)$. 
Table 1 Salinity, water temperature $\left({ }^{\circ} \mathrm{C}\right)$, dissolved oxygen (DO) concentration $\left(\mathrm{mgL}^{-1}\right)$ and saturation $(\%)$ in the water column at each of the ten sites in the Vasse and Wonnerup estuaries in January 2012

\begin{tabular}{|c|c|c|c|c|}
\hline Site & Salinity & Water temp. & DO conc. & DO sat. \\
\hline \multicolumn{5}{|c|}{ (a) Vasse Estuary } \\
\hline 1 & 19.00 & 29.10 & 10.90 & 155.00 \\
\hline 2 & 18.60 & 30.40 & 14.40 & 211.00 \\
\hline 3 & 17.50 & 29.70 & 12.20 & 177.00 \\
\hline 4 & 17.10 & 29.00 & 11.10 & 159.00 \\
\hline 5 & 19.40 & 25.90 & 11.00 & 158.00 \\
\hline Mean & 18.32 & 28.82 & 11.92 & 172.00 \\
\hline SE & 0.44 & 0.77 & 0.66 & 10.53 \\
\hline \multicolumn{5}{|c|}{ (b) Wonnerup Estuary } \\
\hline 6 & 17.30 & 29.60 & 17.60 & 254.00 \\
\hline 7 & 15.60 & 31.00 & 11.90 & 175.00 \\
\hline 8 & 14.20 & 29.20 & 18.10 & 257.00 \\
\hline 9 & 15.40 & 27.20 & 6.28 & 88.00 \\
\hline 10 & 16.20 & 24.00 & 15.10 & 197.00 \\
\hline Mean & 15.74 & 28.20 & 13.80 & 194.20 \\
\hline SE & 0.51 & 1.21 & 2.18 & 30.96 \\
\hline
\end{tabular}

Mean and standard errors for each parameter in each estuary are also provided

Water physico-chemical conditions were also measured immediately upstream of the Vasse surge barrier (Fig. 1). While water temperature there was similar to that recorded in the main body of the two estuaries $\left(27.4{ }^{\circ} \mathrm{C}\right)$, the salinity was substantially greater $(35.7)$ and the dissolved oxygen concentration was far lower and hypoxic $\left(1.5 \mathrm{mgL}^{-1} ; 23 \%\right.$ saturation $)$.

Fish species ranking by abundance and life cycle contribution

A total of 18,148 fish were caught in the nearshore waters of the Vasse and Wonnerup estuaries in January 2012. These fish comprised six species, representing four families. The Atherinidae and Gobiidae were the most speciose, each represented by two species, and together accounted for $>99 \%$ of all fish collected (Table 2).

Table 2 Mean density (fish $100 \mathrm{~m}^{-2} ; \bar{X}$ ), standard deviation (SD), percentage contribution to the overall catch $(\% \mathrm{C})$, rank by density $(\mathrm{R})$, mean total length $(\mathrm{mm} ; \mathrm{L})$ and length range

\begin{tabular}{|c|c|c|c|c|c|c|c|c|c|c|c|c|c|}
\hline \multirow[t]{2}{*}{ Species } & \multicolumn{7}{|c|}{ Vasse Estuary } & \multicolumn{6}{|c|}{ Wonnerup Estuary } \\
\hline & LCG & $\bar{X}$ & SD & $\% \mathrm{C}$ & $R$ & $L$ & $\mathrm{Lr}$ & $\bar{X}$ & SD & $\% \mathrm{C}$ & $R$ & $L$ & $\mathrm{Lr}$ \\
\hline Lepthatherina wallacei & $\mathrm{EF}$ & 810.0 & 1319.6 & 72.58 & 1 & 34.17 & $20-86$ & 29.4 & 66.8 & 6.55 & 3 & 32.7 & $21-46$ \\
\hline Atherinosoma elongata & $\mathrm{EF}$ & 198.0 & 324.8 & 17.74 & 2 & 39.35 & $22-68$ & 236.3 & 324.0 & 52.68 & 1 & 37.6 & $22-60$ \\
\hline Pseudogobius olorum & $\mathrm{EF}$ & 106.0 & 147.1 & 9.50 & 3 & 29.62 & $18-53$ & 182.4 & 378.1 & 40.67 & 2 & 25.0 & $16-43$ \\
\hline Gambusia holbrooki* & FEO & 1.1 & 3.3 & 0.10 & 4 & 24.92 & $18-43$ & & & & & & \\
\hline Carassius auratus* & FEO & 0.8 & 2.2 & 0.07 & 5 & 43.50 & $43-44$ & & & & & & \\
\hline Favonigobius lateralis & EM & & & & & & & 0.43 & 1.09 & 0.10 & 4 & 52.00 & $47-57$ \\
\hline $\begin{array}{l}\text { Total number of } \\
\text { species }\end{array}$ & & 5 & & & & & & 4 & & & & & \\
\hline Mean total density & & 1116.0 & & & & & & 448.5 & & & & & \\
\hline
\end{tabular}

Abundant species in each estuary, i.e. those that contributed $\geq 5 \%$ to the catch, are highlighted in bold. The life cycle guild (LCG; see Potter et al. [2015a] for full details) of each species is also provided ( $E F$ estuarine \& freshwater, $E M$ estuarine \& marine and FEO freshwater estuarine-opportunist). Asterisk denotes that a species has been introduced
(Lr) of each fish species recorded in the Vasse and Wonnerup estuaries in January 2012 
The atherinids Lepthatherina wallacei and Atherinosoma elongata, together with the gobiid Pseudogobius olorum, dominated the fish fauna of the Vasse Estuary, ranking first, second and third, respectively. All three species are capable of completing their lifecycle in estuaries. The same three species were also the most abundant in the Wonnerup Estuary, but differed in their rank order (Table 2). Another goby species, Favonigobius lateralis, was found only in the Wonnerup Estuary, while the reverse was true for two introduced freshwater species, namely the Eastern Mosquitofish Gambusia holbrooki and the Goldfish Carassius auratus.

Mean number of species, density and faunal composition

There was no significant difference $(p=0.614)$ in the mean number of species between the Vasse (3.2) and Wonnerup estuaries (2.8; Fig. 2a). Although the mean total density appeared to differ among estuaries, i.e. 1116 and 449 individuals $100 \mathrm{~m}^{-2}$ in the Vasse and Wonnerup estuaries, respectively, ANOVA did not detect a significant difference in density between the two estuaries $(p=0.482)$. Such a result reflects the large intersite variability in density (Fig. 2b), which ranged between 13 and 3607 individuals $100 \mathrm{~m}^{-2}$ in the Vasse Estuary and between 9 and 1144 individuals $100 \mathrm{~m}^{-2}$ in the Wonnerup Estuary.

The composition of the fish community was shown by one-way ANOSIM not to differ significantly between the Vasse and Wonnerup estuaries $(p=0.413 ; R=0.008)$. This is shown on the associated nMDS ordination plot, where the points representing the sites sampled in the two estuaries do not form discrete groups (Fig. 3). This reflects the fact that SIMPER identified the same three species as typifying the fish fauna of both the Vasse and Wonnerup estuaries, namely L. wallacei, A. elongata and P. olorum. This is illustrated on the shade plot, where at least one of these three species was found at each site and, at seven of the ten sites, all three species were recorded in moderate abundances (Fig. 4). The shade plot also showed that the introduced species only occurred in the Vasse Estuary, with $C$. auratus being found at the two most upstream sites, while G. holbrooki was present at the most upstream site and also further downstream (Fig. 4). The estuarine $\&$ marine gobiid F. lateralis was found only at the most downstream site in the Wonnerup Estuary.
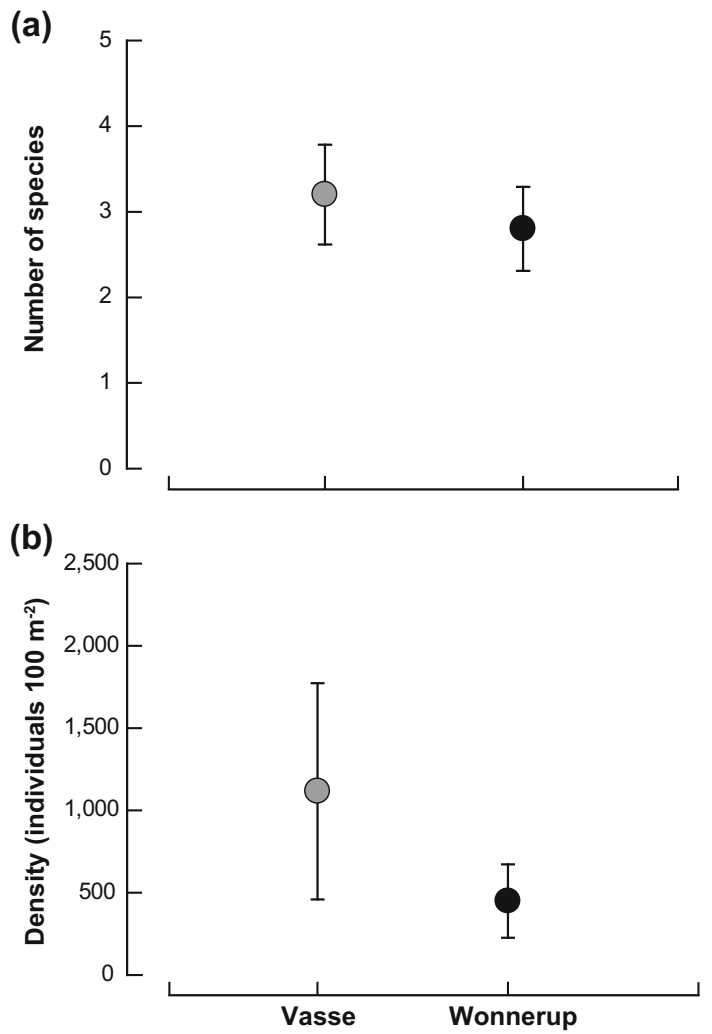

Fig. 2 Mean values \pm 1 standard error for the a number of species and $\mathbf{b}$ density of fishes recorded in the Vasse (dark gray filled circle) and Wonnerup (filled circle) estuaries in January 2012 


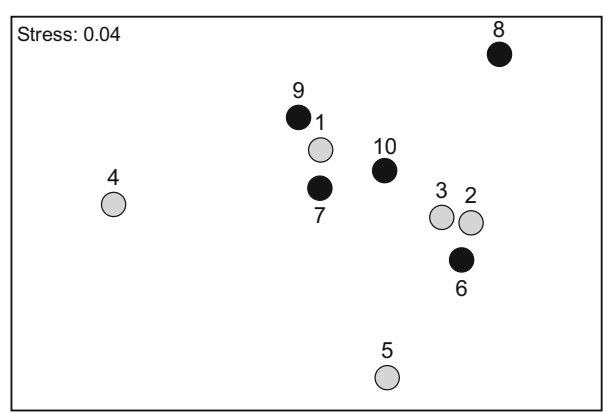

Fig. 3 Non-metric Multidimensional Scaling (nMDS) ordination plot derived from a Bray-Curtis resemblance matrix constructed from the dispersion-weighted, square-root transformed and averaged densities of the fish species recorded at each of the ten sites in the Vasse (dark gray filled circle) and Wonnerup (filled circle) estuaries in January 2012. The numbers above or below the points denote the site that the point represents (see Fig. 1)

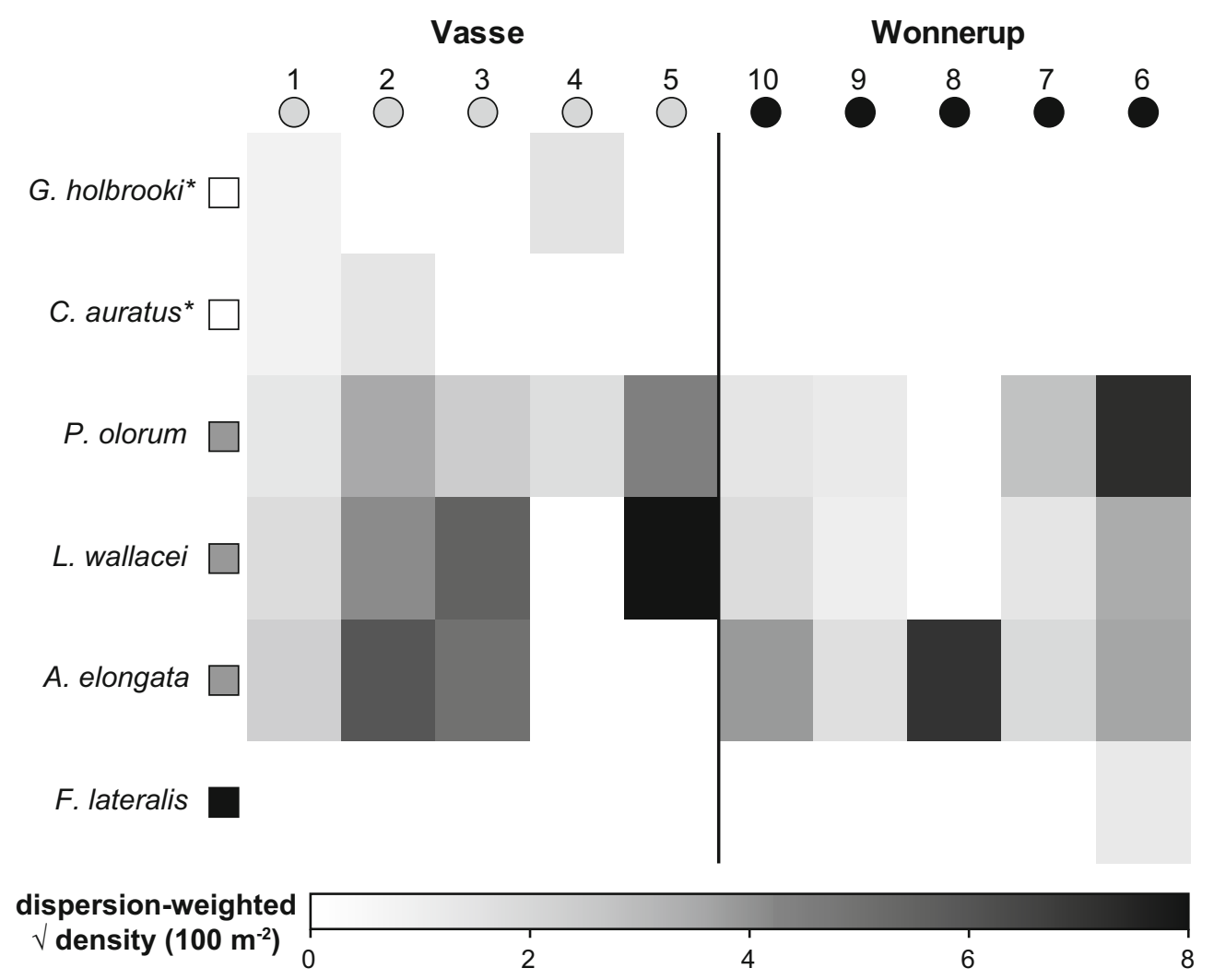

Fig. 4 Shade plot of the dispersion-weighted, square-root transformed and averaged densities $\left(100 \mathrm{~m}^{-2}\right)$ of each fish species recorded at each of the ten sites in the Vasse and Wonnerup estuaries. White areas denote the absence and grey scale the abundance of a species. Vasse Estuary (dark gray filled circle); Wonnerup Estuary (filled circle). Freshwater estuarine-opportunist (open square); Estuarine \& freshwater (gray filled square); Estuarine \& marine (filled square). Asterisk denotes that a species has been introduced

\section{Discussion}

Species abundances and faunal composition

The fish fauna of the Vasse and Wonnerup estuaries in January 2012 was dominated by the atherinids Lepthatherina wallacei and Atherinosoma elongata and the gobiid Pseudogobius olorum. These species, all of 
which complete their entire lifecycle within estuaries, comprised over 99.8 and $99.9 \%$ of the total catches in the Vasse and Wonnerup estuaries, respectively. The prevalence of these species in estuaries, particularly those with a seasonal connection to the ocean, has been reported elsewhere in south-western Australia (Hoeksema et al. 2009; Valesini et al. 2009). The large abundances of these species in these systems, many of which undergo marked changes in salinity (Chuwen et al. 2009), reflect the fact that these species are highly euryhaline (Hoeksema et al. 2006; Veale et al. 2014). The ability to osmoregulate in a broad range of salinities is advantageous in the Vasse and Wonnerup estuaries as salinities can change from $>90$ in April to $<1$ in June (Lane et al. 2011).

The total number of six fish species recorded during the present study is far lower than that recorded in the shallow, nearshore waters of the nearby permanently open Swan-Canning (61), Peel-Harvey (53) and Leschenault (43) estuaries (Valesini et al. 2014; Veale et al. 2014; Potter et al. 2016). It is also less than the number of species found in estuaries on the south coast of Western Australia (i.e. Broke, Wilson and Irwin inlets; 11-20 species), which like the Vasse-Wonnerup, all maintain a seasonal connection to the ocean (Hoeksema et al. 2009). The relatively depauperate nature of the fish fauna of the Vasse and Wonnerup estuaries reflects the fact that the bar at the mouth of Wonnerup Inlet is only open to the ocean for part of the year, thus reducing the opportunity for marine species to penetrate the system (Strydom 2015; Tweedley et al. 2016), and also the fact that, although this study was undertaken during a period when the bar at the mouth of Wonnerup Inlet was open, the movements of marine species into the estuaries are inhibited by the surge barriers (Fig. 1c).

In contrast to the number of species, the total densities of fish were far higher in the Vasse and Wonnerup estuaries than in many of those systems mentioned above (Tweedley 2011). It is thus relevant that, when comparing the fish faunas of five estuaries on the south coast of Western Australia, Hoeksema et al. (2009) noted that L. wallacei, A. elongata and P. olorum, the three most abundant species in the Vasse and Wonnerup estuaries, were far more abundant in the eutrophic Wellstead Estuary than in the oligotrophic Broke Inlet. These authors attributed the large differences in the abundances of these species to the dense stands of macrophytes that occur in the former system. It stands to reason, therefore, that the macrophytes and algae that proliferate in the Vasse and Wonnerup estuaries (Brearley 2005; Chambers et al. 2013; Fig. 1e, f) may play a similar role in supporting the large fish populations reported in the current study. For example, such areas are known to provide a preferred habitat and an abundance of prey for these fish species (Prince et al. 1982; Humphries et al. 1992; Humphries and Potter 1993).

There was no significant difference between the fish faunas of the two estuaries. This result reflects the fact that (1) the faunas of both estuaries were dominated to a similar extent by the same three species, (2) the marked variability in the densities of fish recorded at the various sites within either estuary and (3) that the environments of both estuaries were broadly similar at the time of sampling. Although salinities were significantly higher in the Vasse (18.3) than Wonnerup (15.7) Estuary, these differences were not great enough to inhibit colonisation by the three dominant species, all of which are euryhaline (Hoeksema et al. 2006; Veale et al. 2014). Furthermore, although three of the six species recorded were unique to a particular estuary, none of these species occurred in appreciable densities; for example, F. lateralis was only caught at a single site in the Wonnerup Estuary and constituted only five individuals.

Records of introduced species and their possible impacts

To date, 13 introduced species have been recorded in natural freshwater systems of south-western Australia (Morgan et al. 2004; Beatty and Morgan 2013) and two of these species, G. holbrooki and C. auratus, have been recorded in the lower reaches of the Vasse River (Morgan and Beatty 2007; Beatty et al. 2017). This study has confirmed the presence of these species in the Vasse Estuary, and thus within the boundaries of the Ramsar listing. Such a finding is important as introduced fish have been identified by the Australian Federal Government as a key threat to the ecological character of the Vasse-Wonnerup Wetland System (Australian Government 2011). The poeciliid G. holbrooki, for example, is known to behave in a highly antagonistic manner to other small fishes, causing damage to their fins and even death (Schoenherr 1981; Rowe et al. 2007), and to predate on the eggs and larvae of fish and amphibians (Ivantsoff and Aarn 1999; Pyke 2005). As this species is highly tolerant of changes in salinity, water temperature, dissolved oxygen and turbidity (Cherry et al. 1976; Hubbs 2000) and is extremely abundant in disturbed habitats near urban areas (Lloyd et al. 1986), 
it is likely to be able to survive in the Vasse Estuary despite the large seasonal changes in hydrology. Furthermore, by feeding on zooplankton such as Daphnia, which feed on phytoplankton, G. holbrooki may facilitate, if present in great enough densities, the development of algal blooms, which regularly occur in the system (Hurlbert et al. 1972; Ho et al. 2011).

Of greater concern, however, was the collection of $C$. auratus from the Vasse Estuary. Individuals of this species have been caught frequently and in large numbers from the fresh waters of the lower Vasse River since 2003 (Morgan and Beatty 2007), and an acoustic tracking study revealed C. auratus entered the uppermost (i.e. fresh) section of the Vasse Estuary, raising concern over the potential for further downstream colonisation (Beatty et al. 2017). This cyprinid is a benthic herbivore and through its vigorous feeding activities uproots and consumes vegetation, increases turbidity by resuspending sediments and releases nutrients into the water column (Richardson et al. 1995). Furthermore, C. auratus may exacerbate the regular algal blooms that occur in this system, as the growth of cyanobacteria is stimulated by passage through the intestine of this species (Kolmakov and Gladyshev 2003). From a biological perspective, C. auratus is a known vector for the introduction of parasites and diseases. For example, it is the likely source of the parasitic copepod Lernaea cyprinacea in Western Australia and responsible for the introduction, establishment and spread of Goldfish Ulcer Disease in Australia, which is caused by variants of the pathogenic bacterium Aeromonas salmonicida (Humphrey and Ashburner 1993; Marina et al. 2008). Therefore, its establishment in other estuarine or riverine habitats of the Vasse-Wonnerup system is of great concern.

Although $C$. auratus have previously been recorded in estuaries elsewhere around the world (Maes et al. 1998; Martinho et al. 2007; Henderson and Bird 2010), such records have been typically limited to the upper, oligohaline reaches of these systems and/or have coincided with periods of higher freshwater flows and flushing. The presence of $C$. auratus in the Vasse Estuary during the austral summer, albeit before the system becomes markedly hypersaline (Lane et al. 2011), indicates that this species is capable of surviving in mesohaline environments. Carassius auratus, in the current study, were found in waters with a salinity of 19 , which suggests that this population may have a greater tolerance to salinity than that found in populations elsewhere in the world. For example, Lawson and Alake (2011) found that, although individuals had a high level of acute tolerance to salinities between 1 and 5, none of the fish exposed to higher salinities (i.e. 6-10) remained alive after seven days and, in another study, juvenile $C$. auratus exposed to salinities of 10 died within $24 \mathrm{~h}$ (Jasim 1988). Schofield et al. (2006) found that $C$. auratus was able to persist in salinities $\leq 10$, but exhibited significant mortality at 15 and 20. The ability of $C$. auratus, in the current study, to survive for a protracted period of time in mesohaline salinities raises the concerning possibility that this species might use the estuary as a 'saltbridge' (Bringolf et al. 2005; Schofield et al. 2006; Brown et al. 2007) to access and expand its distribution into new tributaries, i.e. the Sabina and Abba rivers, and to the Wonnerup Estuary and Ludlow River through Malbup Creek, which connects the two estuaries during wet winters (Fig. 1). It is relevant that such movements have been recorded in other freshwater fish species, such as Zander Stizostedion lucioperca, that have previously been considered stenohaline (Brown et al. 2001; 2007).

\section{Future research}

This study represents the first quantitative survey of the fish fauna of the Vasse and Wonnerup estuaries, part of the internationally important Ramsar-listed Vasse-Wonnerup Wetland System, and will provide useful baseline information against which to assess future changes in faunal composition. However, further work is needed to build upon the preliminary findings of this study and to provide a more complete understanding of the ecology of the fish communities of this system. As environmental conditions, such as salinity, water temperature, dissolved oxygen concentration and the composition and abundance of macrophytes change markedly throughout the year (Lane et al. 2011; Tweedley et al. 2013), future work should be undertaken on a seasonal basis, noting that not all areas of the estuaries will contain water at all times of the year. Second, this study focused only on the Vasse and Wonnerup estuaries and no attempt was made to survey other areas of the system, such as Wonnerup Inlet, the Deadwater and the Lower Vasse River Wetlands (Fig. 1). These areas are of significant ecological interest. For example, the Deadwater is known to local fisherman as an important area for juveniles of marine species (Elscot 2000) and has, like the Vasse and Wonnerup estuaries, experienced high nutrient levels, poor water quality, toxic algal blooms and fish kills (Lane et al. 1997; Hart 2014). Given the presence of $C$. auratus in the Vasse Estuary and their potential to use the estuary as a 'saltbridge', a 
laboratory study to determine the chronic and acute salinity tolerance of this population of C. auratus would be valuable, together with sampling of the other tributaries to determine if this invasive species has expanded its range into other water bodies connected to the Vasse Estuary.

Acknowledgements The authors gratefully acknowledge the support given to them during the fieldwork by Alan Clarke (Department of Biodiversity, Conservation and Attractions), Kath Lynch (Department of Water and Environmental Regulation), and Jane Chambers (Murdoch University). Jane Chambers is also thanked for providing the water physico-chemical data. This project was supported by the South West Catchments Council, through funding from the Australian Government, and separately from Murdoch University.

Open Access This article is distributed under the terms of the Creative Commons Attribution 4.0 International License (http:// creativecommons.org/licenses/by/4.0/), which permits unrestricted use, distribution, and reproduction in any medium, provided you give appropriate credit to the original author(s) and the source, provide a link to the Creative Commons license, and indicate if changes were made.

Publisher's Note Springer Nature remains neutral with regard to jurisdictional claims in published maps and institutional affiliations.

\section{References}

Australian Government (2011) Caring for our country site investment guide: Vasse Wonnerup and Geographe Bay. Australian Government, Canberra

Beatty SJ, Morgan DL (2013) Introduced freshwater fishes in a global endemic hotspot and implications of habitat and climatic change. Bioinvasions Rec 2:1-9

Beatty SJ, Allen MG, Whitty JM, Lymbery AJ, Keleher JJ, Tweedley JR, Ebner BC, Morgan DL (2017) First evidence of spawning migration by goldfish Carassius auratus and the implications for control of a globally invasive species. Ecol Freshw Fishes 26:444-455

Brearley A (2005) Ernest Hodgkin's Swanland, 1st edn. University of Western Australia Press, Crawley

Bringolf RB, Kwak TJ, Cope WG, Larimore MS (2005) Salinity tolerance of flathead catfish: implications for dispersal of introduced populations. Trans Am Fish Soc 134:927-936

Brown JA, Moore WM, Quabius ES (2001) Physiological effects of saline waters on zander. J Fish Biol 59:1544-1555

Brown J, Scott D, Wilson R, Gherardi F (2007) Do estuaries act as saline bridges to allow invasion of new freshwater systems by non-indigenous fish species? Biological invaders in inland waters: profiles, distribution, and threats, vol 2. Invading NatureSpringer Series in Invasion Ecology. Springer, The Netherlands, pp 401-414

Chambers JM, Tweedley JR, Clarke A, Paice R (2013) A snapshot survey of the distribution and abundance of macrophytes, macroalgae, phytoplankton and macroinvertebrates of the Vasse-Wonnerup lagoons January 2012. Murdoch University, Perth

Cherry DS, Guthrie RK, Rodgers JH, Cairns J, Dickson KL (1976) Responses of mosquitofish (G. affinis) to ash effluent and thermal stress. Trans Am Fish Soc 105:686-694

Chuwen BM, Hoeksema SD, Potter IC (2009) The divergent environmental characteristics of permanently-open, seasonally-open and normally-closed estuaries of south-western Australia. Estuar Coast Shelf Sci 85:12-21

Clarke KR (1993) Non-parametric multivariate analyses of changes in community structure Australian. J Ecol 18:117-143

Clarke KR, Green RH (1988) Statistical design and analysis for a 'biological effects' study. Mar Ecol Prog Ser 46:213-226

Clarke KR, Chapman MG, Somerfield PJ, Needham HR (2006) Dispersion-based weighting of species counts in assemblage analyses. Mar Ecol Prog Ser 320:11-27

Clarke KR, Gorley RN, Somerfield PJ, Warwick RM (2014a) Change in marine communities: an approach to statistical analysis and interpretation, 3rd edn. PRIMER-E Ltd, Plymouth

Clarke KR, Tweedley JR, Valesini FJ (2014b) Simple shade plots aid better long-term choices of data pre-treatment in multivariate assemblage studies. J Mar Biol Assoc UK 94:1-16

Commonwealth of Australia (2002) Australian catchment, river and estuary assessment 2002, vol 1. National Land and Water Resources Audit, Canberra

Costanza R, d'Arge R, de Groot R, Farber S, Grasso M, Hannon B, Limburg K, Naeem S, O'Neil RV, Paruelo J, Raskin RG, Sutton P, van den Belt M (1997) The value of the world's ecosystems services and natural capital. Nature 387:253-260

Creighton C, Boon PI, Brookes JD, Sheaves M (2015) Repairing Australia's estuaries for improved fisheries production-what benefits, at what cost? Mar Freshw Res 66:493-507

Department of Water (2010) Vasse Wonnerup Wetlands and Geographe Bay water quality improvement plan. Perth, Australia

Elscot SV (2000) Monitoring of fish behaviour in the lower reaches of the Vasse-Wonnerup Wetland System during the summer of 1999/2000. Department of Conservation and Land Management and the Geographe Catchment Council, Busselton

Hallett CS, Valesini FJ, Clarke KR, Hesp SA, Hoeksema SD (2012) Development and validation of fish-based, multimetric indices for assessing the ecological health of Western Australian estuaries. Estuar Coast Shelf Sci 104-105:102-113

Hallett CS, Valesini F, Elliott M (2016) A review of Australian approaches for monitoring, assessing and reporting estuarine condition: III. Evaluation against international best practice and recommendations for the future. Environ Sci Policy 66:282-291 
Harrison TD, Whitfield AK (2004) A multi-metric fish index to assess the environmental condition of estuaries. J Fish Biol 65:683-710

Hart BT (2014) Independent review of the current and future management of water assests in the Geographe catchment. Water Science, Echuca, Australia

Henderson PA, Bird DJ (2010) Fish and macro-crustacean communities and their dynamics in the Severn Estuary. Mar Pollut Bull 61:100-114

Ho SS, Bond NR, Lake S (2011) Comparing food-web impacts of a native invertebrate and an invasive fish as predators in small floodplain wetlands. Mar Freshw Res 62:372-382

Hoeksema SD, Chuwen BM, Hesp SA, Hall NG, Potter IC (2006) Impact of environmental changes on the fish faunas of Western Australian south-coast estuaries. Centre for Fish and Fisheries Research Murdoch University, Perth

Hoeksema SD, Chuwen BM, Potter IC (2009) Comparisons between the characteristics of ichthyofaunas in nearshore waters of five estuaries with varying degrees of connectivity with the ocean. Estuar Coast Shelf Sci 85:22-35

Hubbs C (2000) Survival of Gambusia affinis in a hostile environment. Southwest Nat 45:521-522

Humphrey JD, Ashburner LD (1993) Spread of the bacterial fish pathogen Aeromonas salmonicida after importation of infected goldfish, Carassius auratus, into Australia. Aust Vet J 70(453):454

Humphries P, Potter IC (1993) Relationship between the habitat and diet of three species of atherinids and three species of gobies in a temperate Australian estuary. Mar Biol 116:193-204

Humphries P, Potter IC, Loneragan NR (1992) The fish community in the shallows of a temperate Australian estuary: relationships with the aquatic macrophyte Ruppia megacarpa and environmental variables. Estuar Coast Shelf Sci 34:325-346

Hurlbert SH, Zedler J, Fairbanks D (1972) Ecosystem alteration by mosquitofish (Gambusia affinis) predation. Science 175:639-641

Ivantsoff W, Aarn (1999) Detection of predation on Australian native fishes by Gambusia holbrooki. Mar Freshw Res 50:467-468

Jackson JBC, Kirby MX, Berger WH, Bjorndal KA, Botsford LW, Bourque BJ, Bradbury RH, Cooke R, Jon E, Estes JA, Hughes TP, Kidwell S, Lange CB, Lenihan HS, Pandolfi JM, Peterson CH, Steneck RS, Tegner MJ, Warner RR (2001) Historical overfishing and the recent collapse of coastal ecosystems. Science 293:629-638

Jasim BM (1988) Tolerance and adaptation of goldfish Carassius auratus (L.) to salinity. J Biol Sci Res 19:149-153

Kolmakov VI, Gladyshev MI (2003) Growth and potential photosynthesis of cyanobacteria are stimulated by viable gut passage in crucian carp. Aquat Ecol 37:237-242

Lane JA, Hardcastle KA, Tregonning RJ, Holtfreter S (1997) Management of the Vasse-Wonnerup wetland system in relation to sudden, mass fish deaths. Vasse Estuary Tech Work Gr, Busselton

Lane JAK, Clarke AG, Pearson GB (2007) Waterbirds of the Vasse-Wonnerup Wetlands in 1998-2000 and some comparisons with earlier data. Western Australian Department of Environment and Conservation, Busselton

Lane JAK, Clarke AG, Winchcombe YC (2011) Depth, salinity and temperature profiling of Vasse-Wonnerup wetlands in 1998-2000. Western Australian Department of Environment and Conservation, Busselton

Lawson EO, Alake SA (2011) Salinity adaptability and tolerance of hatchery reared comet goldfish Carassius auratus (Linnaeus 1758). Int J Zool Res 7:68-76

Lloyd LN, Arthington AH, Milton DA (1986) The mosquitofish - a valuable mosquito-control agent or a pest? In: Kitching RL (ed) The Ecology of Exotic Animals and Plants Some Australian Case Histories. Wiley, Brisbane, pp 6-25

Maes J, Taillieu A, Van Damme PA, Cottenie K, Ollevier F (1998) Seasonal patterns in the fish and crustacean community of a turbid temperate estuary (Zeeschelde Estuary, Belgium). Estuar Coast Shelf Sci 47:143-151

Marina H, Beatty SJ, Morgan DL, Doupé RG, Lymbery AJ (2008) An introduced parasite, Lernaea cyprinacea L., found on native freshwater fishes in the south west of Western Australia. J R Soc West Aust 91:149-153

Martinho F, Leitão R, Viegas I, Dolbeth M, Neto JM, Cabral HN, Pardal MA (2007) The influence of an extreme drought event in the fish community of a southern Europe temperate estuary. Estuar Coast Shelf Sci 75:537-546

McAlpine KW, Spice JF, Humphries R (1989) The environmental condition of the Vasse-Wonnerup wetland system and a discussion of management options. Western Australian Environmental Protection Authority Technical Series 31:1-35

Morgan DL, Beatty SJ (2007) Feral Goldfish (Carassius auratus) in Western Australia: a case study from the Vasse River. J R Soc West Aust 90:151-156

Morgan DL, Gill HS, Maddern MG, Beatty SJ (2004) Distribution and impacts of introduced freshwater fishes in Western Australia. NZ J Mar Freshw Res 38:511-523

Patchineelam SM, Kjerfve B, Gardner LR (1999) A preliminary sediment budget for the Winyah Bay estuary, South Carolina, USA. Mar Geol 162:133-144

Potter IC, Hyndes GA (1999) Characteristics of the ichthyofaunas of southwestern Australian estuaries, including comparisons with holarctic estuaries and estuaries elsewhere in temperate Australia: a review. Aust Ecol 24:395-421

Potter IC, Chuwen BM, Hoeksema SD, Elliott M (2010) The concept of an estuary: a definition that incorporates systems which can become closed to the ocean and hypersaline Estuarine. Coast Shelf Sci 87:497-500

Potter IC, Tweedley JR, Elliott M, Whitfield AK (2015a) The ways in which fish use estuaries: a refinement and expansion of the guild approach. Fish Fish 16:230-239

Potter IC, Warwick RM, Hall NG, Tweedley JR (2015b) The physico-chemical characteristics, biota and fisheries of estuaries. In: Craig J (ed) Freshwater Fisheries Ecology. Wiley-Blackwell, USA

Potter IC, Veale LJ, Tweedley JR, Clarke KR (2016) Decadal changes in the ichthyofauna of a eutrophic estuary following a remedial engineering modification and subsequent environmental shifts. Estuar Coast Shelf Sci 181:345-363

Prince J, Potter I, Lenanton R, Loneragan N (1982) Segregation and feeding of atherinid species (Teleostei) in south-western Australian estuaries. Mar Freshw Res 33:865-880

Pyke G (2005) A review of the biology of Gambusia affinis and G. holbrooki. Rev Fish Biol Fish 15:339-365 
Richardson MJ, Whoriskey FG, Roy LH (1995) Turbidity generation and biological impacts of an exotic fish Carassius auratus, introduced into shallow seasonally anoxic ponds. J Fish Biol 47:576-585

Rowe DK, Smith JP, Baker C (2007) Agonistic interactions between Gambusia affinis and Galaxias maculatus: implications for whitebait fisheries in New Zealand rivers. J Appl Ichthyol 23:668-674

Schoenherr AA (1981) The role of competition in the displacement of native fishes by introduced species. In: Naiman RJ, Stolz DL (eds) Fishes in North American Deserts. Wiley, New York, pp 173-203

Schofield PJ, Brown BE, Fuller PF (2006) Salinity tolerance of goldfish, Carassius auratus, a non-native fish in the United States. Fla Sci 69:258-268

Sheaves M, Baker R, Nagelkerken I, Connolly RM (2015) True value of estuarine and coastal nurseries for fish: incorporating complexity and dynamics. Estuaries Coasts 38:401-414

Strydom NA (2015) Patterns in larval fish diversity, abundance, and distribution in temperate South African estuaries. Estuaries Coasts 38:268-284

Tweedley JR (2011) The Relationships Between Habitat Types and Faunal Community Structure in Broke Inlet, Ph.D., Murdoch University, Western Australia

Tweedley JR, Warwick RM, Valesini FJ, Platell ME, Potter IC (2012) The use of benthic macroinvertebrates to establish a benchmark for evaluating the environmental quality of microtidal, temperate southern hemisphere estuaries. Mar Pollut Bull 64:1210-1221

Tweedley JR, Chambers JM, Paice R (2013) Sediment accumulation and resuspension in the Vasse-Wonnerup Wetlands and its relationship to internal nutrient cycling. Murdoch University, Perth

Tweedley JR, Warwick RM, Clarke KR, Potter IC (2014) Family-level AMBI is valid for use in the north-eastern Atlantic but not for assessing the health of microtidal Australian estuaries. Estuar Coast Shelf Sci 141:85-96

Tweedley JR, Warwick RM, Potter IC (2016) The contrasting ecology of temperate macrotidal and microtidal estuaries. Oceanogr Mar Biol Annu Rev 54:73-171

Tweedley JR, Warwick RM, Hallett CS, Potter IC (2017) Fish-based indicators of estuarine condition that do not require reference data. Estuar Coast Shelf Sci 191:209-220

Valesini FJ, Coen NJ, Wildsmith MD, Hourston M, Tweedley JR, Hallett CS, Linke TE, Potter IC (2009) Relationships between fish faunas and habitat type in south-western Australian estuaries. Project 2004/045. Draft Final Report for Fisheries Research and Development Corporation. Murdoch University, Perth

Valesini F, Tweedley J, Clarke K, Potter I (2014) The importance of regional, system-wide and local spatial scales in structuring temperate estuarine fish communities. Estuaries Coasts 37:525-547

Veale L, Tweedley JR, Clarke KR, Hallett CS, Potter IC (2014) Characteristics of the ichthyofauna of a temperate microtidal estuary with a reverse salinity gradient, including inter-decadal comparisons. J Fish Biol 85:1320-1354

Wetland Research and Management (2007) Ecological character description: Vasse-Wonnerup wetlands Ramsar site south-west Western Australia. Wetland Research and Management, Perth

Wildsmith MD, Rose TH, Potter IC, Warwick RM, Clarke KR, Valesini FJ (2009) Changes in the benthic macroinvertebrate fauna of a large microtidal estuary following extreme modifications aimed at reducing eutrophication. Mar Pollut Bull $58: 1250-1262$ 